\title{
Beckett in the Dock: Censorship, Biopolitics, and the Sinclair Trial
}

\author{
Lloyd (Meadhbh) Houston \\ University of Oxford, England
}

Copyright (c) 2019 by Lloyd (Meadhbh) Houston. This text may be archived and redistributed both in electronic form and in hard copy, provided that the author and journal are properly cited and no fee is charged for access.

\begin{abstract}
Of all the actions of the Irish Censorship of Publications Board, one of the most often cited, but least critically examined, is the suppression of Samuel Beckett's More Pricks Than Kicks (1934). This article aims to recover a fuller picture of how censorship of More Pricks affected Beckett, particularly in his attitudes to the biopolitical policing of ethnonational identity. To do so, it examines Beckett's involvement in Harry Sinclair's 1937 libel action against Oliver St John Gogarty, and the crucial role that the suppression of More Pricks played in discrediting Beckett as a witness. In contrast to previous, "personal" readings of the trial, it explores how the libellous passages of Gogarty's As I Was Going Down Sackville Street (1937) offered an anti-Semitic portrait of Sinclair and his family in which ethnic alterity and sexual deviance are presented as synonymous, and how Gogarty's barrister appropriated this rhetorical strategy to target Beckett. In the process, it offers a deep contextualisation of Beckett's anti-natalism, anti-nationalism, and longstanding aversion to censorship, by emphasising their relationship to his experiences of the operation of biopolitics in the emergent Free State and a wider European context during the trial and its aftermath.
\end{abstract}

Key Words. Beckett, Biopolitics, Censorship, Anti-Semitism, Pro-Natalism.

Resumen. De todas las acciones llevadas a cabo por la Junta de Censura de Publicaciones de Irlanda, uno de los casos más frecuentemente citados, pero rara vez analizado de forma crítica, es la prohibición del libro de Samuel Beckett More Pricks Than Kicks (1934). En este artículo se pretende ofrecer un panorama general de cómo la censura de More Pricks afectó a Beckett, concretamente en lo tocante a sus actudides con respecto a la vigilancia biopolítica de la identidad nacional. Para tal fin, se examinará la implicación de Beckett en el caso de libelo de 1937 de Harry Sinclair contra Oliver St John Gogarty, así como el papel crucial que jugó la prohibición de More Pricks para desacreditar a Beckett como testigo. Frente a previos análisis, más personales, del juicio, en este artículo se estudia la forma en la que los párrafos difamatorios del libro de Gogarty, As I Was Going Down Sackville Street (1937), ofrecían un retrato antisemita de Sinclair y de su familia por medio de los cuales la alteridad étnica y las 
desviaciones sexuales se presentaban como sinónimos, y cómo el abogado de Gogarty se apropió de esta estrategia retórica para atacar a Beckett. A lo largo del artículo se ofrecerá también una completa contextualización del antinatalismo de Beckett, así como de su antinacionalismo y de su duradera aversión a la censura. En este sentido se relacionarán estas actitudes con la forma en la que Beckett vivió las acciones biopolíticas del emergente Estado Libre de Irlanda, todo ello dentro de un amplio contexto europeo en la época en la que se produjo el juicio y también posteriormente.

Palabras clave. Beckett, biopolítica, censura, antisemitismo, pronatalismo.

It shall not be lawful for any person [to print, publish, or sell] any book or periodical publication (whether appearing on the register of prohibited publications or not) which advocates or which might reasonably be supposed to advocate the unnatural prevention of conception or the procurement of abortion or miscarriage or any method, treatment, or appliance to be used for the purpose of such prevention or such procurement.

Censorship of Publications Act, 1929: Part IV.16.(1)

Sterilization of the mind and apotheosis of the litter suit well together. Paradise peopled with virgins and earth with decorticated multiparas. Samuel Beckett. "Censorship in the Saorstat"

One of the most fruitful focal-points for recent scholarship on both Beckett's attitudes to biopolitics and his relationship to the cultural politics of the Irish Free State has been the debates surrounding Ireland's 1929 Censorship of Publications Act and its infamous prohibition of all printed matter relating to birth control and abortion. On the one hand, critics from John Harrington to Paul Stewart have presented Beckett's much-discussed anti-natalism as a response to the Act, which he felt deployed a blend of philistinism, cultural isolationism, and moral panic to sponsor the cultural and political hegemony of an ill-qualified Catholic ruling elite. ${ }^{1}$ On the other, Seán Kennedy and James McNaughton have emphasised Beckett's disquiet in the face of efforts by representatives of the Protestant minority to use the Act as a rallying cry to sponsor the demographic, political, and cultural resurgence of an increasingly beleaguered Ascendancy. ${ }^{2}$ In both cases, however, Beckett's response to what was arguably his most direct experience of Irish censorship, and, by extension, the Catholic-nationalist regime of pro-natalist biopolitics with which he felt it to be bound up, has received relatively little attention: the suppression of his first collection of short fiction, More Pricks Than Kicks (1934) by the Irish Censorship Board. The collection was placed on the "Index of Forbidden Books" in Ireland on 20 October 1934, two months after Beckett had finished the first draft of his excoriating analysis of publications control in Ireland, "Censorship in the Saorstat" (written for the Bookman, but not published until 1983). ${ }^{3}$ However, while the collection's suppression might be assumed to have been a significant (and potentially distressing) landmark in the young author's fledgling literary career, neither the published Letters nor any of the major accounts of Beckett's life directly record his response to the event. ${ }^{4}$

While the present article cannot remedy this perhaps tellingly self-censorious silence on Beckett's part directly - the necessary archival materials either do not survive or never existed - it nevertheless aims to recover a fuller picture of the ways in which the suppression 
of More Pricks affected the young author, particularly in his attitudes to the biopolitical policing of ethno-national identity. To do so, it examines Beckett's involvement in Harry Sinclair's 1937 libel action against the infamous Dublin surgeon, author, and raconteur, Oliver St John Gogarty, and the crucial role that the suppression of More Pricks played in discrediting Beckett as a witness. Given the embarrassment, anxiety, and shame the highly publicised Sinclair trial caused Beckett, it has traditionally been read in terms of its impact on his personal reputation in Dublin and its role in cementing his conviction to leave his homeland for good. ${ }^{5}$ However, as Emilie Morin has rightly emphasised, such a narrowly "personal" reading of the trial risks overlooking its fraught political stakes and eliding the noxious blend of anti-Semitism and xenophobia of which Gogarty stood accused (70-78). I would further argue that what it particularly ignores is the extent to which the libellous passages of Gogarty's As I Was Going Down Sackville Street (1937) and the trial to which they gave rise reflect and extend the same biopolitical debates over sexual conduct and the boundaries of Irish identity which the passage of the Censorship Act had catalysed. In what follows, I seek to address this lacuna by exploring the ways in which these debates inscribe themselves both in Gogarty's anti-Semitic portraits of Sinclair, his brother William (Beckett's uncle), and their grandfather, Morris Harris, in which ethnic alterity and sexual deviance are presented as synonymous, and in the attack his barrister was to mount against Beckett and his writing, in which a similar rhetorical strategy is deployed. In the process, I aim to offer a deeper contextualisation of Beckett's anti-natalism, anti-nationalism, and longstanding aversion to censorship, by emphasising their relationship to his experiences of the operation of biopolitics in the emergent Free State and a wider European context. Finally, by exploring the ways in which these themes surface in Beckett's most explicitly "Irish" piece of postcensorship prose, Murphy (1938), I hope to suggest some of the ways in which an awareness of this biopolitical context could inform future readings of Beckett's prose and to propose some avenues for further exploration in this domain. To do so, it is first necessary to outline the debates surrounding the passage and operation of the Censorship Act and their implications for the operation of biopolitics in Ireland.

\section{Censorship, Biopolitics, and Ireland}

The 1929 Censorship of Publications Act has long served as a locus classicus for those exploring the role of biopolitics in early twentieth-century Ireland. The fraught history and complex cultural politics of the Act's infamous proscriptions concerning birth control literature are well documented. ${ }^{6}$ Though originally prompted by a campaign by Catholic action groups to protect Ireland from the perceived threat of the English periodical press, debates around the Act soon came to centre on questions of fertility, population control, and religious freedom (Ferriter 185-191). The key lines of argument were neatly summarised by WB Yeats in a 1928 article for the Spectator in which he claimed that:

Although it was almost certain that Catholic Ireland, thinking 'birth control' wrong in principle, would follow the lead of countries that, being in sore need of soldiers and cheap labour, think it undesirable and legislate against it, those who belong to the Church of Ireland or to neither Church should compel the fullest discussion. The Government is forbidden under the Treaty to favour one religion at the expense of another, which does not mean that they may not propose legislation asked for by one Church alone, but that they must show that the welfare of the State demands it. (Yeats 391) 
As Yeats suggests, arguments in favour of the Act often fused Catholic fertility doctrine with a strain of anti-Malthusian thought common in contemporary European nationalism to present birth control as a threat to the physical and moral integrity of the Irish people. Catholic periodicals such as the Irish Rosary regularly advocated for censorship as a means to curtail the "modern mania of race suicide" ("Delta" 305-306), while pro-censorship TDs such as JJ Byrne invoked the spectre of population decline to emphasise the urgency of their cause:

To the vast majority of the people the limitation, the control of births, or the infliction of race suicide upon this nation is one that is bitterly resented ... The French population actually exceeded the German population in 1850 . To-day the German population stands at 69 millions and the French population at 391/2 millions. Is that for the benefit of France? ... Does it make for the production of a better race [?] (Dáil Éireann, 19 October 1928)

One of the most vocal advocates for the Act in this regard was Oliver Gogarty, who, though he had reservations about its efforts to regulate indecency in literature, was unstinting in his support of its prohibition of material relating to birth control on pointedly ethno-national grounds:

No one who has any care for a nation's welfare can for one moment countenance contraceptive practices, which are a contradiction of a nation's life. In England the condition of the miners and the unemployed is as it is because England has allowed its capital to go into yellow, brown and black labour, so that the Government tolerates clinics for education in the practice of contraception. The English Government has practically told the unemployed that they should not cumber the earth. That is in the land in which heroes are contraceived [sic]. We must make the Bill capable of dealing adequately, without undue hardships on the public, with this contraceptive literature. (Seanad Éireann, 11 April 1929)

Meanwhile, as the framing of Yeats's remarks makes clear, arguments against the Act typically combined a commitment to what was presented as a Protestant tradition of intellectual liberty with a concern for the "welfare of the State" tacitly rooted in a eugenicist model of population control. The letters pages of the Irish Times during the period in which the Bill was being debated abound in comments such as those from Church of Ireland Rector Dudley Fletcher, who noted that, as the Catholic population were "not allowed to hold an independent opinion" on the subject out of deference to "ecclesiastical authority", it was the duty of the Protestant minority to remind them that, if "more individuals are born than the food supply can sustain, the surplus must starve or be killed off" (Dudley Fletcher 4). In both cases, through the Act and the debates to which it gave rise discourses of sexual health, eugenics, and population control became intimately bound up with a broader competition for political influence and cultural capital between a variety of intellectual, governmental, and confessional factions within the Free State. ${ }^{7}$

As noted above, Samuel Beckett's objections to the Act and what he perceived to be its sectarian, pro-natalist agenda are no less well documented. As the abortive 1934 essay "Censorship in the Saorstat" makes clear, Beckett saw the Act as an exemplary piece of "panic legislation", in which the "painful tension between life and thought" (Beckett, Disjecta 87) was to be resolved in the favour of the former, irrespective of its negative impact on the physical, intellectual, or cultural well-being of the nation. Where once "to waive the off 
chance of a reasonable creature" had been a "mere mortal sin" (which is to say, a matter of private, denominational conscience), Beckett objected that the Censorship Act had rendered such precautions a "slapup social malfeasance", undermining the boundaries of the secular state and the principle of intellectual liberty though the "civic obligation to throttle reason itself" where it was expressed in a form "obnoxious" to the Catholic state (Beckett, Disjecta 87).

Like many of his fellow opponents to the Act, Beckett was particularly keen to debunk what he perceived to be the spurious claims to purity upon which the model of Irish identity the Act sought to sponsor was based. In a pointed jibe at the ideal of rural peasant virtue so often fetishised by cultural nationalists, Beckett argued that the Act was essentially redundant because, "as a characteristic agricultural community", the Irish had "something better to do than read" (Beckett, Disjecta 87). Building on this image of the Irish as a people more licentious than literate, Beckett highlighted the paradox of an Act which sought to limit Irish readers' access to sexually explicit reading matter, even as it tacitly sought to encourage them to reproduce:

The pure Gael, drawing breath from his heels, will never be permitted to defile his mind with even such fairly clean dirt as the Black Girl in her Search for God so long as he can glorify his body to the tune of half a dozen byblows, white as phthisis, in search for a living. This yoke will not irk him. (Beckett, Disjecta 87)

As the epigraph to this article shows, for the young Beckett, the "Sterilization" of the Irish mind through censorship and the "apotheosis" of the Irish "litter" through unchecked fertility constituted the mutually reinforcing aims of an increasingly populist and pious nationalism with which he would have no truck. So intense was this pro-natalist drive, in Beckett's eyes, that it was to be pursued even where it violated the Catholic moral code it was apparently intended to reflect (by sponsoring the "byblows" of extra-marital sex) or the pseudo-eugenic aspirations it was intended to realise (by refusing to regulate the spread of infections such as "phthisis" - tuberculosis - then thought to be hereditary).

Efforts to affront this regime have been found throughout the Beckettian oeuvre, from the narrator's insistent call for his pregnant lover to "[a]bort, abort" (Beckett, First Love 78) in Premier amour/First Love (written 1947, published 1970) to the caustic portrait of the Lynch family in Watt (1953), whose "[f]ive generations and twenty-eight souls" (Beckett, Watt 87) pathologically flout the precepts of eugenics by continuing to reproduce with élan, despite being afflicted with poverty, hunger, and a litany of hereditary degenerative conditions. However, as I suggested in my opening, notwithstanding this robust body of research, the ways in which Beckett's sensitivity to and rejection of pro-natalism were leant urgency by his personal experiences of censorship have received surprisingly little scholarly coverage. This has resulted in a diminished sense of the ways in which Beckett came to perceive the Censorship Act as an instrument of cultural, ethnic, and biopolitical policing that resonated unsettlingly with both recent developments in the eugenicist ethno-nationalism of various strands of European Fascism and Irish anti-Semitism. As I shall demonstrate in what follows, in both cases Beckett's role in the libel trial provoked by Oliver St John Gogarty's As I Was Going Down Sackville Street was to prove central in sharpening his critique of biopolitics in Ireland and elsewhere.

\section{"I can smell a Jew": Sex, Anti-Semitism, and the Sinclairs}

As Emilie Morin has emphasised, the "innuendos and rumours relayed in Gogarty's memoir and at the libel trial were far more pernicious and serious than they have been made out to be" 
(73). In one particularly lurid passage, Gogarty describes Sinclair's grandfather, Morris Harris, and the habits he bequeathed to his grandsons:

Now, there was an old usurer who had eyes like a pair of periwinkles on which somebody had been experimenting with a pin, and a nose like a shrunken tomato, one side of which swung independently of the other. The older he grew, the more he pursued the immature and enticed little girls into his office. That was bad enough; but he had grandsons, and these directed the steps of their youth to follow in grandfather's footsteps, with more zeal than discrimination. (Gogarty, Sackville Street 70-71)

The passage's exaggeratedly grotesque style almost occludes the debts its blatant antiSemitism and rhetorical structure owe to late nineteenth and early twentieth-century models of scientific racism. As Sander Gilman has shown, since the mid-nineteenth century, Jewishness and pathology (particularly mental illness) had been virtually synonymous in European medical and popular discourse. ${ }^{8}$ Jean Martin Charcot spoke for many during one of his hugely influential Tuesday lessons at the Salpêtrière in 1888 when he stressed "combien, dans la race, les accidents nerveux de tout genre ... se montrent incomparablement beaucoup plus fréquents qu'ailleurs" [how incomparably more frequent nervous accidents of all types are among the [Jewish] race than elsewhere] (Charcot 11).

This predisposition towards neurological illness was attributed (in often contradictory ways) to the sexual alterity of the Jewish, who were held by popular opinion and sexology alike to be both pathologically endogamous, and dangerously licentious. ${ }^{9}$ This intellectual heritage is most visible in Gogarty's strategy of linking physical manifestations of what he views as the ethnic and cultural alterity of the Harris-Sinclairs (the grandfather's eyes and nose) with an itinerary of their allegedly rapacious, legally prohibited, and morally repugnant sexual appetites (child abuse and indiscriminate sexual predation). Indeed, the very manner in which Gogarty introduces his description of Morris's continued line ("That was bad enough; but he had grandsons") seems intended to frame his abusive sexual preferences as an inevitable hereditary taint which would have been better left unpropagated. In an accompanying piece of doggerel Gogarty reiterates this caricature, and the model of mutually reinforcing sexual deviance and ethnic alterity on which it is predicated:

Two Jews grew in Sackville Street

And not in Piccadilly,

One was gaitered on the feet,

The other one was Willie.

They kept a shop for objects wrought

By Masters famed of old,

Where you, no matter what you bought

Were genuinely sold.

But Willie spent the sesterces

And brought on strange disasters

Because he sought new mistresses

More keenly than old Masters.

(Gogarty, Sackville Street 65)

As in Gogarty's portrait of Harris, traditional anti-Semitic tropes (usury), markers of visible difference (Harry's gaiters - an apparently common piece of attire among Dublin's Jews), 
imputations of rapacious sexual misconduct (Willie's transparently phallic name and predilection for new and expensive "mistresses"), and suggestions of sexual pathology ("strange disasters") combine to present the brothers as fundamentally alien to Irish culture. ${ }^{10}$ Even the convoluted evocation of Piccadilly seems to offer a shrill testament to this perceived ethnic difference, implying through its redundant negation that the Jewish brothers would be more at home in the English metropolis than on a Dublin thoroughfare.

The ways in which such rhetoric resonates with the racial policies of Nazi Germany are clear enough. By the time of the Sinclair trial, the Nazi regime's "Gesetz zum Schutze des Deutschen Blutes und der Deutschen Ehre" [law for the protection of German blood and German honour], which, in an effort to enshrine the perceived "purity" of the German people, prohibited marital or extra-marital relationships between German citizens and Jews (who had been stripped of their citizenship), had been in operation for over two years. ${ }^{11}$ However, it also participates in a long-standing tradition of Irish anti-Semitism. As Morin has shown, this characterisation of the Harris-Sinclairs had its roots in another, no less ethnically-charged trial. In the final months of 1906, Harris's wife, Kathleen - an Irish Catholic by birth - sought to divorce him on grounds of adultery, cruelty, blasphemy, and paedophilia, and a variety of criminal activity which she alleged he had committed with the help of his grandsons (Morin 74). Though the jury ultimately cleared Harris of every charge save cruelty (the minimum necessary for the divorce to proceed), the accusations were given a wide and eager airing in the press. ${ }^{12}$ As the Harris divorce proceedings were reaching their apex, Gogarty began publishing a series of articles in Arthur Griffith's Sinn Féin in which he offered a diagnostic anthropology of "Ugly England" and its corrupting influence in Ireland. In these gymnastically chauvinistic articles, the "venereal excess" (Gogarty, "Ugly" 3) of the British Army, the "gross materialism" (Gogarty, "Ugly II" 3) of the English mercantile class, and the "wormy" (Gogarty, "Ugly III" 3) - which is to say syphilitic - blood of the Anglo-Irish Ascendancy are presented as linked manifestations of a decadent and degenerative Jewish influence to which all of Ireland's ills may be attributed: "I can smell a Jew ... and in Ireland there's something rotten" (Gogarty, "Ugly III" 4). At times this whiff of Jewishness is largely analogical - a rhetorical means by which to identify and denigrate what Gogarty perceives to be the most reprehensible of England's many failings:

England becoming Jewry... It explained how many things! ... that shopkeeping, moneying instinct; that hatred of things generous or artistic: -make ye no graven images; that filthy sensuality, unrelieved even by gaiety; that furtive and narrow timidity, and that panic-stricken, cowardly way of taking revenge ... (Gogarty, "Ugly" 3)

However, at others it is presented in a pointedly anthropometric key, coded as a series of identifiable racial features whose pathological influence infuses itself into the blood of any nation to which it is introduced:

If the race has really gained supremacy in the country, the race-type ought to be marked in the physiognomy of physique of the people. Yes; distinctly it was perceptible... when allowance was made for the blending of the races: - The shopgirl type with her anaemic face and aquiline nose, her eyes often brown and closely set; hair scanty. Her teeth are bad, for her palate is narrow, and she cannot breathe well through that long nasal cavity of hers. Yes; she lacks the better characteristics of either race, as is the case always in half-breeds... Oh Israel! (Gogarty, "Ugly" 3) 
While it is impossible to say whether Gogarty was aware of the Harris divorce proceedings while writing these articles, his emphasis on the dysgenic character of "half-breeds" is suggestive given how frequently the press emphasised the perceived incompatibility of Harris's Judaism and Kathleen's Irish-Catholic heritage. ${ }^{13}$ Whatever their relation to the Harris divorce, as Gogarty's emphasis on "race-type", "physiognomy", and the various congenital defects with which the young shop-girl is afflicted suggests, his comments drew on a long-standing tradition of racial science and anti-Semitic discourse which figured Jews as a degenerate and degenerative sexual threat to a nation's physical and cultural integrity. Irish manifestations of these discourses in this period were not confined to Gogarty's articles, also surfacing in United Ireland's coverage of the Dreyfus affair and in the anti-Semitic sermons which sparked the 1904 Limerick Pogrom. ${ }^{14}$ However, the "Ugly England" series stands out in its medical and anthropological register, its emphasis on the inherited and pathological nature of Jewish racial difference, and its consistent elision of Jewishness and Englishness all features which recur in Gogarty's characterisation of Harris and the Sinclair brothers.

Further compounding the biopolitical bite of Gogarty's anti-Semitic caricature was the immediate political context in which it was made. Damning under any circumstances, Gogarty's accusations of Harris's child abuse would have carried a particularly pointed charge in the wake of the Carrigan Committee. Established by the Cosgrave government in 1930 amid the same atmosphere of moral panic which had prompted the passage of the Censorship of Publications Act, the Committee had been tasked with gathering evidence of Irish sexual conduct as the basis for a more stringent Criminal Law Amendment Act. However, the Committee's Report, which detailed "an alarming amount of sexual crime", "increasing yearly" and frequently involving "criminal interference with girls and children" (Carrigan 14), was ultimately deemed unpublishable by the new Fianna Fáil government. ${ }^{15}$ The controversy surrounding the Report simmered until 1935, when a revised Criminal Law Amendment Act was passed. As a member of the Seanad, Gogarty would have been at least aware of the nature and general character of the Report, even if he had not personally had access to it. Such a familiarity is reflected in his remarks in a 1935 Irish Times article in which he criticises the Censorship Board for moving beyond their perceived remit of suppressing birth control literature: "If this country had produced great sinners there would be something to censor but even the Carrigan report was not made public so we didn't know what is the enormity of our crimes" ("Censorship of Books"). Diarmaid Ferriter has rightly warned against reading the Carrigan Report and the decisions which led to its suppression as the products of a univocal "hegemonic discourse" of Irish purity or a unified "containment culture" surrounding sexuality in the Free State (136). Nevertheless, Beckett certainly appears to have perceived the Censorship Act and the Criminal Law Amendment Act as linked parts of a larger regulatory regime surrounding sexual conduct and Irish identity. His first act upon receiving the commission for "Censorship in the Saorstat" from the Bookman editors appears to have been to attempt to acquire a copy of the latter, as yet undrafted, Act:

The Bookman writes, postponing all articles on Gide, Rimbaud \& kindred dangers, in favour of one on the wicked Censorship in Ireland. By all means. I tried to get the Criminal Law Amendment Act, but it has not yet been issued in the form of a bill, or even taken shape as such according to Eason's expert. (Letters I 218)

As such, Beckett would have been well placed to detect the ways in which Gogarty's portrait of Harris as an alien sexual threat to the vulnerable young women of Ireland was inflected both by the Report and by the climate which prompted its suppression, drawing on its image of an Ireland in which the sexual abuse of young girls was common, even as it displaces responsibility for such crimes away from the Irish (and Catholic) population and onto a 
perceived ethnic outsider. Called upon to defend his work, Gogarty contended that the "usurer" was a "composite photograph" intended "to throw discredit on usury and moneylending" in general ("900 DAMAGES" 5), tacitly acknowledging that even if the specific libel against Harris and the Sinclairs had been unintentional, the characterisation of Jews as a sexual threat to vulnerable Irish girls was wholly deliberate. It is unimaginable that Beckett, freshly returned from a prolonged stay in a Germany increasingly vocal in its embrace of Nazi racial ideology to an Ireland in the midst of its own flirtation with Eoin O'Duffy's Emerald-tinted Fascism, would have been deaf to the implications of Gogarty's remarks, and the rhetoric of sexual hygiene and eugenicism which underpinned them. ${ }^{16}$ Nor, would he have missed the ways in which their influence was reflected in the efforts of Gogarty's representatives to discredit him in court.

\section{"a man who indulged in the psychology of sex": Beckett in the Dock}

The ways in which Gogarty's barrister, JM Fitzgerald, KC, sought to undermine Beckett's credibility as a witness by emphasising his continental connections, dubious scholarly interests, and obscene literary output are well established. However, read in the light of the above analysis, it becomes clear that this line of attack was not only a piece of shrewd legal theatre, but a strategically deployed reprisal of the logic and tone of Gogarty's text in which the Censorship Act would play a crucial role. Fitzgerald began his attack by ascertaining Beckett's present address ("Ah Paris ... He lives in Paris"), and the nature of his academic output: "Have you written a book about a man called Marcel Prowst?" (Cronin 271). The trap was an obvious one, with Beckett's impeccably pronounced correction, along with his Parisian lodgings, combining to position him from the outset in the minds of the jury as a morally suspect adherent of foreign decadence. This impression was compounded when Fitzgerald enquired if Proust was "a man who indulged in the psychology of sex?" (Cronin 271). The question was damning on a number of levels. For a lay-person, Fitzgerald's use of the verb "indulge" framed the "psychology of sex" as an obscene act which, the question implied, Beckett had sought to document and excuse. However, for those in the know, Fitzgerald's reference to Havelock Ellis' Studies in the Psychology of Sex (1897-1928, banned in Ireland in 1931) seems intended to invoke its most infamous volume, Sexual Inversion (published in 1897 and tried for obscenity in Britain in 1898), and the various modes of samesex desire, queer experience, and gender-non-conformity it catalogued. Compounding these insinuations of sexual alterity, there was the question of Proust's ethnic background. The subject had been given a caustic public airing only a year before by the Abbé Ernest Dimnet in a widely reported address to the Royal Dublin Society in which he had attributed what he perceived to be the want of religious feeling in Proust's work to the influence of his Jewish mother. ${ }^{17}$ Indeed, as Emilie Morin highlights, in an even-handed letter to the Irish Times Harry Sinclair had in fact taken Dimnet to task for the "race exceptionalism" (Sinclair, "Mehr Licht", 17 November 1936, 9) which underpinned his dismissal of Proust and the critique of Zola which had preceded it. ${ }^{18}$ In such a context, while it is impossible to ascertain how cognisant Kennedy was of Proust's Jewish heritage, it is hard not to read his comments on "Prowst" in conversation with his cross-examination of Sinclair, in which he commented on the "strange names" taken by Jews whose names are "unpronounceable" ("DR OLIVER GOGARTY SUED" 5). The question of ethnicity was further stressed when Fitzgerald emphasised Beckett's family connections to the Sinclairs and asked whether he "called [himself] a Christian, Jew or Atheist" ("DR OLIVER GOGARTY SUED" 5) and Beckett declined all three labels. Fitzgerald's opening salvo thus positioned Beckett as an ethnically ambiguous Parisian blasphemer who had appropriated sexually-explicit scientific reading 
matter to sponsor the non-heteronormative and, by extension, anti-natal oeuvre of a foreign, Jewish author.

When Beckett sensibly (if disingenuously) declared himself unaware of Proust's interest in the subject, Fitzgerald changed tack, deliberately eliding the Proust essay and More Pricks Than Kicks by asking how long it had been "before [Beckett's] book was banned by the Censorship Board of Ireland" and characterising the text as "blasphemous and obscene" ("DR OLIVER GOGARTY SUED" 5). ${ }^{19}$ He pressed his point by quoting a passage from the short story "A Wet Night", in which the Polar Bear (a caricature of Beckett's French Professor at Trinity, Thomas Rudmose-Brown) discusses Christ with a no-nonsense Jesuit:

The Lebensbahn ... of the Galilean is the tragi-comedy of the solipsism that will not capitulate. The humilities and retro me's and quaffs of sirreverance are on a par with the hey presto's, arrogance and egoism. He is the first great self-contained playboy. The cryptic abasement before the woman taken red-handed is as great a piece of megalomaniacal impertinence as his interference in the affairs of his boy-friend Lazarus. (Beckett, More Pricks 50-51) ${ }^{20}$

The features of this description which Fitzgerald intended to highlight in order to prejudice the jury against Beckett when he enquired whether this was not a blasphemous caricature of the Redeemer are obvious enough. However, without wishing to credit Fitzgerald with a subtler engagement with Beckett's work than might be expected of a working barrister, many features of the passage and its position within the story make it resonate strikingly with both Gogarty's remarks and with the proscriptions of the Censorship Act. As Andy Wimbush has noted, what animates the Polar Bear in this moment is the irreconcilability of two mutually contradictory images of Christ which have been central to Christian theology since the middle-ages: the Ecce Homo [behold the man] or suffering Christ, bowed and resigned to his fate, and the Christus Victor [Christ the victor], conquering death through his miraculous raising of Lazarus and his eventual resurrection (78). Wimbush argues that, for Beckett, the Christus Victor's triumphant failure to capitulate undermines the authenticity and appeal of the Ecce Homo's solipsistic resignation. However, read in the context of the Censorship Act, what is striking are the ways in which the revivifying imperative the triumphant Christ apparently embodies are undermined throughout the passage through implicit and explicit references to non-reproductive sexual activity. The unrelenting "solipsism" of Christ (which links him both to Belacqua and the, as-yet unconceived, Murphy) is given a distinctly, if paradoxically, sexual flavour through his figuration as "the first great self-contained playboy".

This reference to Synge's infamous 1907 comedy, the Playboy of the Western World, and the furore it generated by depicting a community of peasant women in the West of Ireland pursuing the eponymous playboy-parricide Christy Mahon with increasing sexual rapacity, transforms Christ's solipsism into an act of unrelenting onanistic self-love. ${ }^{21}$ Likewise, the Polar Bear's linking of Christ's abasement before an adulteress with his "interference" with his "boy-friend" Lazarus foregrounds the obvious sexual and homoerotic overtones of the latter jibe in a manner that collocates Christ at his most robustly triumphant with a range of non-reproductive and morally censured forms of sexual activity, all of which were deemed obscene under the terms of the Censorship Act. The Catholic triumphalism which Beckett and others had detected in the Act's restrictions on birth control literature is thus subjected to an exuberant sexualised pastiche in a manner and tone comparable to that of the later Bookman essay. As John Pilling cautions, it is dangerous to present the Polar Bear's position as identical to Beckett's in this moment - the Jesuit ultimately outwits the Polar Bear, obliging him to pay both their tram fares (74). Nevertheless, by understanding the ways in which 
Beckett was publicly obliged to account for such remarks in response to both a pro-natalist regime of moral hygiene founded on a Catholic politics of fertility and the sexualised antiSemitic libel it had been conscripted to justify, it becomes possible to arrive at a fuller sense of the political stakes of Beckett's aversion to censorship, nationalism, and pro-natalism. As the final section of this article will show, this is particularly the case in the immediate aftermath of the Sinclair trial, and in Beckett's first piece of post-trial fiction, Murphy.

\section{"quite exceptionally anthropoid": Biopolitical Beckett}

On the one hand, Beckett's response to the experience of censorship appears to have been decidedly pragmatic and even careerist. A flavour of this practical attitude can be caught in his response to a commission from Jack Kahane's Obelisk Press to translate Sade's Les 120 Journées de Sodome [the 120 days of Sodom] (written 1785, published in French 1904), an offer which, after a period of anxious deliberation, Beckett provisionally accepted on 08 March 1938. In a letter to George Reavey of 20 February 1938, Beckett outlined his concerns over the effect it would have on his literary "situation in England" and how it "might prejudice future publications" (Beckett, Letters I 604) of his own work there. Beckett emphasized that the "surface" was of "an unheard of obscenity \& not 1 in 100 will find literature in the pornography, or beneath the pornography" (Beckett, Letters I 604). While Beckett did not "mind the obloquy", acknowledging that it would advance his reputation in certain literary circles, he did not wish to be "spiked as a writer" (Beckett, Letters I 604), nor was he prepared to publish the translation anonymously or pseudonymously. Revisiting the issue two days later, Beckett emphasised that he was afraid that he might be "banned \& muzzled retrospectively" and that his "freedom of literary action" (Beckett, Letters I 608) in England and the United States would be compromised. The matter was ultimately resolved when the commission was delayed by Kahane and quietly dropped. Whether the exclusive preoccupation with England and America in these letters reflects an ambitious young author's desire for a wider readership or suggests that Beckett believed that his literary reputation in Ireland was already compromised beyond repair is unclear. ${ }^{22}$

On the other hand, if Beckett's correspondence in this period captures a sense of his pragmatic concerns surrounding censorship, his creative writing registers more clearly still his awareness of the biopolitical dimensions of Irish censorship. As noted above, Murphy's efforts to bait the "filthy censor" are seldom far to seek, with "music, MUSIC, MUSIC" (Beckett, Murphy 147) serving as a consistent euphemistic metaphor for the various forms of commoditised sexual activity which animate the novel. However, when framed in relation to Beckett's experiences at the hands of both the Irish Censorship Board and Gogarty's barrister in the Sinclair trial, it becomes possible to detect the more specific, biopolitically inflected goad offered by the novel's characterisation of a figure such as Miss Counihan. This is most apparent in the description of her Dublin-based tryst with the unscrupulous Wyle:

A kiss from Wylie was like a breve tied, in a long slow amorous phrase, over bars' times its equivalent in demi-semiquavers. Miss Counihan had never enjoyed anything quite so much as this slowmotion osmosis of love's spittle.

The above passage is carefully calculated to deprave the cultivated reader.

For an Irish girl Miss Counihan was quite exceptionally anthropoid. Wylie was not sure he cared altogether for her mouth, which was a large one. The kissing surface was greater than the rosebud's, but less highly toned. Otherwise she did. It is superfluous to describe her, she was just like any other beautiful Irish girl, except, as noted, more markedly anthropoid. (Beckett, Murphy 75) 
The provocations the passage offers to the censorship regimes of Ireland, Britain, and America are clear enough - all three specify the intention to "deprave" a reader as a key test for obscenity. ${ }^{23}$ However, as the narrator's insistence on Miss Counihan's status as an archetypal Irish beauty makes clear, the specific target of Beckett's satire is not simply censorship in general, but Ireland's censorship regime, and the ethno-nationalist sexual hygiene agenda for which he believed it to be the vehicle. The passage's confrontational antinationalist intent inscribes itself in its Dublin setting, which the narrator, in a playful false negation intended to avoid any possibility of libel, specifies is "not Wynn's hotel" (Beckett, Murphy 75) - a building located almost directly opposite the spiritual centre of the Easter Rising, the General Post Office. Beckett thus uses a deliberately self-defeating mode of selfcensorship to confront an idealised image of Irish identity at its most piously messianic with what he presents as an apparently no less exemplary manifestation of its own debauchery.

Reading this passage in relation to the biopolitical policing of Irish identity showcased at the Sinclair trial, it becomes possible to put pressure on the apparent tension between the narrator's insistence on the superfluity of describing a figure so evocative of a general Irish type, and their equally great insistence on highlighting her "exceptionally anthropoid" features. In reality, the dichotomy is a false one: both descriptive strategies and the registers in which they are conducted are of a piece, reflecting the same anthropometric gaze and ethnographic perspective through which Gogarty's caricature of the Harris-Sinclairs had been conducted. Just as the Harris-Sinclairs were presented by Gogarty as licentious sexual deviants on the basis of their ethnic alterity and non-human characteristics (Harris's "periwinkle" eyes), Miss Counihan is presented as an eagerly promiscuous figure, whose exaggerated mouth, "highly-toned" rosebud (presumably a reference to her labia or anal sphincter), and "anthropoid" (almost, but, crucially, not entirely "human") appearance mark her out as a hyper-eroticised and evolutionarily-retrograde figure, uniquely equipped for nonreproductive sexual activity. Beckett's characterisation of Miss Counihan as "more markedly anthropoid" than other beautiful Irish women is particularly damning in that it situates the majority of Irish women in a taxonomic bracket even further removed from humanity than her status as a "higher primate". ${ }^{24}$ I have noted elsewhere the ways in which this description replicates tropes of simianization prevalent in nineteenth-century British Hibernophobic caricatures in a manner that appears to betray a degree of anti-Catholic sectarian animus on Beckett's part. ${ }^{25}$ However, when read in the context of the Sinclair trials, it becomes possible to detect in this moment a subversive desire on Beckett's part to emphasise the continuity between this anti-Irish anthropometric tropology and both the tradition of Irish anti-Semitism to which Gogarty had contributed and the pro-natal ethno-nationalism to which he had lent his parliamentary support. In doing so, Beckett suggests how, in sponsoring a model of postindependence Irish identity premised upon a model of sexual and ethnic purity rooted in statesponsored reproductive sexual activity, Ireland not only risked making some disastrous contemporary ideological bedfellows, but embracing the very xenophobic biopolitical logic through which British rule had once been justified and naturalised. As this example suggests, a more detailed understanding of Beckett's experiences of censorship, anti-Semitism, and biopolitics during the Sinclair trial offers not only a heightened awareness of the ways in which Beckett perceived and critiqued their influence at a local and European level, but also a clearer sense of the political tensions at the heart of the young Beckett's iconoclastic relationship with his homeland. In doing so, it offers future scholarship an incitement to read Beckett's engagement with the cultural and sexual politics of Europe and Ireland not in oppositional terms, but as interimplicated and mutually-reinforcing areas of concern for the author and his oeuvre. 


\section{Notes}

${ }^{1}$ Examples include Harrington 21-27 and 35-39, Hatch, Bixby 9-14, Stewart (Chapter 3), and Houston.

${ }^{2}$ See S. Kennedy and McNaughton (Chapter 2).

${ }^{3}$ The decision, which received ministerial approval on 20 October, was made public in the state newsletter, Iris Oifigiúil, on 23 October ("Prohibition Order" 986). The collection was removed from the "Index" by the 19521953 annual report of the Board (Annual Reports 9).

${ }^{4}$ In a letter to McGreevy of 07 August 1934 Beckett notes that the Bookman has commissioned a piece on "the wicked Censorship in Ireland". He appears to have completed the piece by 27 August, when he writes again to McGreevy, informing him that he has "ground out miserably 1800 words" on the subject "which they will surely reject" (Beckett, Letters I 218).

5 Bair 281-285, Knowlson 275-281, Cronin 268-275, and O’Connor 276-285.

${ }^{6}$ Major studies include Adams, Carson, Pašeta, and Martin.

${ }^{7}$ For a fuller discussion of these debates, see Houston.

${ }^{8}$ Gilman, Difference and Pathology Chapters 6 and 8 and Gilman, The Jew's Body.

${ }^{9}$ Gilman, Difference and Pathology 153-6, Weininger (Chapter 13).

${ }^{10}$ The Sinclairs' legal representative, Albert E. Wood, identified the "strange disasters" to which Willie fell victim as "venereal disease" ("900 DAMAGES" 5).

${ }^{11}$ For a transcript and translation of the "Gesetz zum Schutze des Deutschen Blutes und der Deutschen Ehre", see "Nuremberg Race Laws". For accounts of Nazi racial policy and its relationship to eugenics and medical science, see Burleigh and Wippermann, Proctor, Hutton, and Weiss.

${ }^{12}$ Morin cites coverage by the Freeman's Journal, Irish Independent, and Irish Times (Morin 74-75).

13 "Her Life a Hell" 5, "Humanity: Jew and Christian" 7.

${ }^{14}$ Keogh and McCarthy 20-5 and Creagh.

${ }^{15}$ For accounts of the Report's suppression, see F Kennedy, Finnane, and Ferriter 134-45.

${ }^{16}$ For an account of Beckett's awareness of and reaction to these discourses, see Nixon. For accounts of Irish Fascism and O'Duffy's role in Irish politics, see White and McGarry.

17 "MACHIAVELLI OF STATESMEN" 4 and "FROM A PARIS BALCONY" 10.

${ }_{18}^{18}$ Morin 75, Sinclair, "Mehr Licht”, 17 November 1936, 9, and Sinclair, "Mehre Licht", 1 December 1936, 3.

19 "DR OLIVER GOGARTY SUED" 5.

${ }^{20}$ The passage is transposed virtually unaltered from the conclusion of Beckett's abortive first novel, Dream of Fair to Middling Women, composed between May 1931 and July 1932 (Beckett, Dream 199-241).

${ }^{21}$ For accounts of the public and press reaction which the initial run of Playboy of the Western World (1907) provoked and the tensions over national identity and sexual conduct which they reflect see Kilroy, Tifft, Harris Chapter 2, Levitas, Theatre of Nation Chapter 5, and Levitas "Mirror up to Nurture".

${ }^{22}$ In either case, Beckett's direct concern with the workings of Irish censorship was to persist until at least 1940, when he may be found securing the latest "Register of Prohibited Publications" for James Joyce (Beckett, Letters I 676).

${ }^{23}$ Dáil Éireann, “Censorship of Publications Act, 1929” and Potter Chapter 1.

24 "Anthropoid, Adj. and n.,".

${ }^{25}$ Houston 558. For more on this tradition see Curtis and de Nie.

\section{Works Cited}

“£900 DAMAGES AWARDED IN LIBEL ACTION.” The Irish Times. November 24, 1937, 5.

Adams, Michael. Censorship: The Irish Experience. Dublin: Scepter Books, 1968.

OED Online. “Anthropoid, Adj. and n.” March 2019. http://www.oed.com/view/Entry/8427?redirectedFrom=anthropoid.

Bair, Deirdre. Samuel Beckett: A Biography. London: Vintage, 1990.

Beckett, Samuel. Disjecta: Miscellaneous Writings and a Dramatic Fragment. Ed. Ruby Cohn. London: J. Calder, 1983. 
Dream of Fair to Middling Women. Eds. Eoin O'Brien and Edith Fournier. New York: Arcade Publishing, 1992.

. More Pricks Than Kicks. Ed. Cassandra Nelson. London: Faber and Faber, 2010.

- Murphy. Ed. J.C.C. Mays. London: Faber, 2009.

- The Expelled / The Calmative / The End \& First Love. Ed. Christopher Ricks. London: Faber, 2009.

- The Letters of Samuel Beckett. Eds. Martha Dow Fehsenfeld, Lois More Overbeck, George Craig, and Dan Gunn. Vol. I: 1929-1940. 4 vols. Cambridge: Cambridge University Press, 2009.

- Watt. Ed. Chris Ackerley. London: Faber and Faber, 2009.

Bixby, Patrick. Samuel Beckett and the Postcolonial Novel. Cambridge: Cambridge University Press, 2009.

Burleigh, Michael, and Wolfgang Wippermann. The Racial State: Germany, 1933-1945. Cambridge: Cambridge University Press, 1991.

Carlson, Julia, ed. Banned in Ireland: Censorship \& the Irish Writer. London: Routledge, 1990.

Carrigan (Chairman), William. Report of the Committee on the Criminal Law Amendment Acts (1880-85), and Juvenile Prostitution. Dublin: Stationery Office, 1931.

"Censorship of Books. Views of a Free State Senator. The Board's Great Fault." Irish Times, February 6, 1935.

“Censorship of Publications Act, 1929. Prohibition Order." Iris Oifigiúil, no. 85 (23 October 1934): 986.

Censorship of Publications Bill, 1928 - Second Stage (Resumed), Pub. L. No. 26.6 (1928). https://www.oireachtas.ie/en/debates/debate/dail/1928-10-19/2/.

Charcot, Jean Martin. Leçons Du Mardi à La Salpêtrière: Policlinique, 1888-1889. Paris: Progrés Médical, 1889.

Creagh, Fr John. "Jewish Trading, Its Growth in Limerick, Address to the Confraternity." Munster News. 13 January 1904. 35-36.

Cronin, Anthony. Samuel Beckett: The Last Modernist. London: Harper Collins, 1996.

Curtis, Lewis Perry. Apes and Angels: The Irishman in Victorian Caricature. Rev. ed. Washington, DC: Smithsonian Institution Press, 1997.

Dáil Éireann. "Censorship of Publications Act, 1929." Irish Statute Book, July 2014. http://www.irishstatutebook.ie/1929/en/act/pub/0021/print.html.

De Nie, Michael Willem. The Eternal Paddy: Irish Identity and the British Press, 1798-1882. Madison: University of Wisconsin Press, 2004.

"Delta". "Race Suicide and Souperism". Irish Rosary XXXII 4 (April 1928): 305-307.

Department of Justice. Annual Reports of the Censorship of Publications Board and of the Censorship of Publications Appeal Board for the Years Ended 31st December, 1952 and 31st December, 1953. Dublin: Stationery Office, 1954.

"DR. OLIVER GOGARTY SUED FOR LIBEL: QUOTATIONS FROM BOOK ABOUT DUBLIN 'VENOMOUS LIBELS,' SAYS COUNSEL DUBLIN DIVORCE CASE RECALLED.” Irish Times. 23 November 1937. 5. 
Dudley Fletcher. "Letters to the Editor: The Free State Censorship Bill". Irish Times. 5 September 1928. 4.

Ferriter, Diarmaid. Occasions of Sin: Sex and Society in Modern Ireland. London: Profile Books, 2009.

Finnane, Mark. "The Carrigan Committee of 1930-31 and the "Moral Condition of the Saorstát." Irish Historical Studies 32, no. 128 (2001): 519-536.

"FROM A PARIS BALCONY: LECTURE BY ABBE DIMNET." Irish Times. 14 November 1936. 10.

Gilman, Sander L. Difference and Pathology: Stereotypes of Sexuality, Race, and Madness. Ithaca: Cornell University Press, 1985.

Gilman, Sander L. The Jew's Body. New York: Routledge, 1991.

Gogarty, Oliver St John. As I Was Going Down Sackville Street: A Fantasy in Fact. London: Rich and Cowan, 1937.

. "Ugly England (I)." Sinn Féin. 15 September 1906. 3.

"Ugly England (II).” Sinn Féin. 24 November 1906. 3.

"Ugly England (III)." Sinn Féin. 1 December 1906. 3-4.

Harrington, John P. The Irish Beckett. Syracuse, N.Y: Syracuse University Press, 1991.

Harris, Susan C. Gender and Modern Irish Drama. Bloomington: Indiana University Press, 2002.

Hatch, David A. 'Samuel Beckett's 'Che Sciagura' and the Subversion of Irish Moral Convention." Samuel Beckett Today/Aujourd'hui (2007): 241-255.

"Her Life a Hell." Irish Independent. 3 November 1906.

Houston, Lloyd (Meadhbh). "'Sterilization of the Mind and Apotheosis of the Litter': Beckett, Censorship, and Fertility." The Review of English Studies 69, no. 290 (31 January 2018): 546-564.

"Humanity: Jew and Christian.” Sunday Independent. 4 November 1906.

Hutton, Christopher. Race and the Third Reich: Linguistics, Racial Anthropology and Genetics in the Dialectic of Volk. Cambridge: Polity, 2005.

Kennedy, Finola. "The Suppression of the Carrigan Report: A Historical Perspective on Child Abuse." Studies: An Irish Quarterly Review 89, no. 356 (2000): 354-363.

Kennedy, Seán. "First Love: Abortion and Infanticide in Beckett and Yeats." Samuel Beckett Today/Aujourd'hui (2010): 79-91.

Keogh, Dermot, and Andrew McCarthy. Limerick Boycott 1904: Anti-Semitism in Ireland. Douglas Village, Cork: Mercier Press, 2005.

Kilroy, James. The "Playboy" Riots. Dublin: Doleman Press, 1971.

Knowlson, James. Damned to Fame: The Life of Samuel Beckett. London: Bloomsbury, 1997.

Levitas, Ben. "Mirror up to Nurture: JM Synge and His Critics." Modern Drama 47. 4 (2004): 572-584. 
"MACHIAVELLI OF STATESMEN: ABBE DIMNET ON MUSSOLINI: GULF BETWEEN NAZISM AND FASCISM.” Irish Times. 13 November 1936. 4.

Martin, Peter. Censorship in the Two Irelands, 1922-1939. Dublin: Irish Academic Press, 2006.

McGarry, Fearghal. Eoin O'Duffy: A Self-Made Hero. Oxford: Oxford University Press, 2007.

McNaughton, James. Samuel Beckett and the Politics of Aftermath. Oxford: Oxford University Press, 2018.

Morin, Emilie. Beckett's Political Imagination. Cambridge: Cambridge University Press, 2017.

Nixon, Mark. Samuel Beckett's German Diaries, 1936-1937. London: Continuum, 2011.

Holocaust Encyclopaedia. "Nuremberg Race Laws." 11 September 2019. https://encyclopedia.ushmm.org/content/en/article/nuremberg-laws.

O'Connor, Ulick. Oliver St John Gogarty: A Poet and His Times. Dublin: O'Brien Press, 2000.

Pašeta, Senia. "Censorship and Its Critics in the Irish Free State, 1922-1932." Past \& Present 232. 1 (2003): 193-218.

Pilling, John. Samuel Beckett's "More Pricks Than Kicks": In a Strait of Two Wills. London: Bloomsbury, 2013.

Potter, Rachel. Obscene Modernism: Literary Censorship and Experiment 1900-1940. Oxford University Press, 2013.

Proctor, Robert N. Racial Hygiene: Medicine under the Nazis. Cambridge, Mass: Harvard University Press, 2000.

Wikisource. "Regina v. Hicklin (1868)," March 2019. https://en.wikisource.org/wiki/Regina_v._Hicklin.

Seanad Éireann. Censorship of Publications Bill, 1928 - Second Stage (Resumed)., Pub. L. No. 12.10 (1929). https://www.oireachtas.ie/en/debates/debate/seanad/1929-04-11/3/.

Sinclair, Henry M. "Letters to the Editor: Mehr Licht." The Irish Times. 17 November 1936. 9.

—. "Letters to the Editor: Mehr Licht." The Irish Times. 1 December 1936. 3.

Stewart, Paul. Sex and Aesthetics in Samuel Beckett's Work. New York: Palgrave Macmillan, 2011.

Tifft, Stephen. "The Parricidal Phantasm: Irish Nationalism and the Playboy Riots." In Nationalisms \& Sexualities, edited by Andrew Parker, Mary Russo, Doris Sommer, and Yaeger. London: Routledge, 1992. 313-332.

Weininger, Otto. Sex and Character: Authorised Translation from the Sixth German Edition. London: William Heinemann, 1903.

Weiss, Sheila Faith. The Nazi Symbiosis: Human Genetics and Politics in the Third Reich. Chicago: University of Chicago Press, 2010.

White, Martin. "The Greenshirts: Fascism in the Irish Free State, 1935-1945." Queen Mary, University of London, 2004. http://qmro.qmul.ac.uk/xmlui/handle/123456789/1696. 
Wimbush, Andy. "Hey Prestos and Humilities: Two of Beckett's Christs." Journal of Beckett Studies 25. 1 (April 2016): 78-95.

Yeats, W.B. “The Irish Censorship.” Spectator. 28 September 1928. 391-92.

Lloyd (Meadhbh) Houston is Hertford College - Faculty of English DPhil Scholar in Irish Literature in English at the University of Oxford. Their thesis explores Irish modernism and the politics of sexual health. Other research interests include literature and obscenity, queer modernisms, and the social history of medicine. Their work has appeared in the Review of English Studies, the Library, and the Irish Studies Review, where they were awarded the 2017 British Association of Irish Studies Essay Prize, and has been featured in the Times Literary Supplement, the Guardian, and on the Modernist Podcast.

lej.houston@outlook.com 